Interfaces

\title{
Synesthesia in Percy Bysshe Shelley's ekphrasis: from audible paintings to tangible ideas
}

\section{Fabien Desset}

\section{(2) OpenEdition}

1 Journals

\section{Electronic version}

URL: http://journals.openedition.org/interfaces/239

DOI: 10.4000/interfaces.239

ISSN: 2647-6754

\section{Publisher:}

Université de Bourgogne, Université de Paris, College of the Holy Cross

\section{Printed version}

Date of publication: 1 January 2015

Number of pages: 187-218

ISBN: 9780983175247

ISSN: $1164-6225$

\section{Electronic reference}

Fabien Desset, "Synesthesia in Percy Bysshe Shelley's ekphrasis: from audible paintings to tangible ideas", Interfaces [Online], 36 | 2015, Online since 01 January 2018, connection on 06 January 2021 URL: http://journals.openedition.org/interfaces/239 ; DOI: https://doi.org/10.4000/interfaces.239

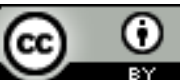

Les contenus de la revue Interfaces sont mis à disposition selon les termes de la Licence Creative Commons Attribution 4.0 International. 


\title{
SYNESTHESIA IN PERCY BYSSHE SHELLEY'S EKPHRASIS: FROM AUDIBLE PAINTINGS TO TANGIBLE IDEAS
}

\author{
Fabien Desset
}

\section{Introduction}

Synesthesia in Percy Bysshe Shelley's poetry has already been studied by Glenn O'Malley in his Shelley and Synesthesia (1964) and mentioned by critics like Richard Fogle, but usually without any reference to the poet's prose and more particularly his ekphrases of paintings. The transaesthetic passage from painting to literary texts yet involves a relative change of emphasis from the visual to the audible or oral and from physical to mental experience, and can therefore be described as synesthetic.

This paper will thus try to see to what extent synesthesia helps the poet talk about or rewrite visual works of arts, especially paintings, and to what extent ekphrasis can be described as synesthetic and help regenerate figurative language or what Shelley calls "relations of things" in "A Defence of Poetry." To better understand the importance and aspects of synesthesia in Shelley's ekphrasis, it will first be necessary to look at its significance in his poetry and thought, from the definition of sense analogies as metaphors to their metaphysical dimension. Then, the study proper of ekphrasis will contextualise synesthesia in Shelley's aesthetic discourse and theory, which are mainly borrowed from Johann Joachim Winckelmann and the poet's experience of the Italian chiaroscuro.

\section{The Significance of Synesthesia in Shelley's Poetry}

1. "Unapprehended relations of things:" synesthesia as metaphor

Shelley's "synesthetic art" or "imagery," as O'Malley calls it, gives shape to his subtlest impressions and poetic visions. It also helps him regenerate language and poetry when, like dead metaphors, figurative language no longer discloses the poetic "spirit" behind the "form" that he distinguishes in his preface to "Prometheus Unbound" (1818-1820) and in "A Defence of Poetry" (1821):

Their [poets'] language is vitally metaphorical; that is, it marks the before unapprehended relations of things, and perpetuates their apprehension, until the words which represent them, become through time signs for portions and classes of thoughts instead of pictures of integral thoughts; and then if no new poets should arise to create afresh the associations which have 
been thus disorganized, language will be dead to all the nobler purposes of human intercourse. These similitudes or relations are finely said by Lord Bacon, to be 'the same footsteps of nature impressed upon the various subjects of the world' - and he considers the faculty which perceives them as the storehouse of axioms common to all knowledge. (Poetry and Prose 482)

Although the poet does not specifically refer to synesthesia, since he deals with figurative language as a whole, O'Malley (17-18) agrees that this passage is what comes shortest of a definition, that is to say, "language which describes one sense experience in terms that "belong' to one or more of the other senses" (3). Shelley here extends the notion of metaphor to "similitudes," "associations" or "unapprehended relations of things," which indeed include synesthesia: firstly, synesthesia "associates" different sensations or words referring to different senses, like sight and hearing, because there is a "similitude" between them. This is what Shelley's quotation from Francis Bacon suggests too, as it refers to the similar delight which the author of The Advancement of Learning (1605-23) derived from the various senses. ${ }^{1}$ These metaphorical associations were in fact in the air at the time, and among other proponents of synesthetic associations were Bertrand Castel's failed attempt at the creation of a colour organ, or Isaac Newton's parallel, in Opticks (1704), between the spectrum bands in a prism and the octave intervals in the musical gamut, which O'Malley believes Shelley "had in mind from the start" (24).

Secondly, synesthetic associations are often perceived as "new" or "unapprehended," because they transcend sensory categories and, like the oxymoron or conceit, more obvious associations. In O'Malley's words, they are "sometimes regarded as eccentric or even abnormal in origin" (3), which is all the truer of Shelley since he "favored analogies which were seldom or never reported by psychologists' informants, such as analogies involving odors with sights and sounds" (7). This infuriated Shelley's early reviewers, for whom his poetry was "anarchic" or "absurd" (15-16), although the poet in fact "inclin[ed] toward the intellectual" senses of sight and hearing, "especially in his early poetry" (24).

The main synesthetic images O'Malley identifies (and summarises pages 26-34) are the analogy, derived from William Jones (Physiological Disquisitions, 1781), between the Aeolian harp and prism or rainbow, which, once synesthetically combined, form an "air prism" or "Memnonian principle" converting light into sound or vice versa (45-51); the "Venus complex," which, like the Pythagorean music of the crystalline spheres, "fuses the harmonies and illuminations of love in the light of Venus;" unseen singing birds, like the skylark, or odorous flowers, which are sometimes substituted for that planet because of their similar harmonizing influences; the "supernal 'illumination' [...] broken

Actually, O'Malley (17) notes that the reference is to De Augmentis Scientiarum, book III, chapter I. The corresponding passage in The Advancement of Learning is in book II, section v. 
down into 'colours' that affect all the senses, and affect them so that synesthetic analogies disclose an underlying unity," for instance, prismatic emanations or embodiments of the white light-like One Love, like Emily and her "soul-sisters" in Epipsychidion (1821) or Asia and her sister Oceanids in "Prometheus Unbounds"; "negative intersense analogy" inspired by Dante (85), like "silent splendour" in The Triumph of Life $(1822,1.413)$ echoing "I came to a place where all light was mute" in The Inferno (1:28); and, after Richard Fogle, water-figures and the stream of sound, especially in "Prometheus Unbound" (144). ${ }^{2}$

However, O’Malley omits the passage on the "disorganization" of metaphors. This is yet a third reason for interpreting the "disorganized" "classes of thought" as also referring to synesthesia, or rather, "dead synesthesia." O'Malley all the same refers to "faded metaphors or synesthetic transfers of ordinary speech" (24), like "imbibed no fleeting radiance" or the Homeric "web of talk" in The Retrospect. Cwm Elan 1812 (1. 83, 99, The Poems 1:224; Iliad 3:212). He finds them especially in Shelley's early poetry, but also calls the poet's interchange of heavenly flowers and earthly stars in Adonais (1821) an "age-old conceit" (30) partly derived from Plato's pun on the name "Aster." However "unapprehended" they might have been at the beginning, synesthesiae may thus end up disorganised and turn into poetic conventions, clichés or dead metaphors. The distinction between "warm" and "cold" colours is a more obvious example, especially for a study of Shelley's allusions to the visual arts and ekphrasis, "the verbal representation of visual representation" (Heffernan 3).

\section{Beyond the limits of figurative language, and ekphrasis}

Like the oxymoron, paradox and conceit, synesthesia is perhaps a more conscious metapoetic trope than metaphor or metonymy. In using it, the poet deliberately tests the limits of language and perception. O'Malley (6) and June Downey (Creative Imagination 100-101) before him make a distinction between "spontaneous" (true or psychological) and "deliberate" (pseudo or literary) synesthesia, the latter sort characterising Shelley's "imaginative use of sense analogies." At the same time, literary synesthesia is made up of words and sounds, so that the poet's hope of transcendence may

Richard Fogle analyses Asia's boat symbolism as a synesthetic complex "of music-water-color-motion. [...] The metaphors of the boat, the swan, and the 'silver waves' are definite and strongly concrete. [...] Since, however, the boat is a symbol of the soul, we do not strongly feel the sense-transference in 'waves-singing,' for the image has committed itself to a subjectivity in which one moves at will from plane to plane" (Imagery 131). He also points out that "Water, motion, and music are generally equated, and referred to the motion and the vibration of the spirit" ("Image and Imagelessness" 32-33). 
also turn into despair, as in Adonais, in which words and the sister arts are too "weak" to represent the Ideal or Truth: “[...] Rome's azure sky, / Flowers, ruins, statues, music, words, are weak / The glory they transfuse with fitting truth to speak" (466-468, Poetry and Prose 405). While literary synesthesia tries to overcome the limits of figurative language, it also hints at its impossibility. ${ }^{3}$

This is particularly true of ekphrasis, in which the poet is faced with what Gotthold Ephraïm Lessing calls "the limits of painting and literature" in Laokoon (1766). In his note to Scopas's "Niobe" (Notes on Sculptures, 1819-1820), Shelley indeed writes, "It is difficult to speak of the beauty of her countenance, or to make intelligible in words the forms from which such astonishing loveliness results" (Shelley's Prose 353). As Lessing puts it in Shelley's French expanded edition of Johann Joachim Winckelmann's History of Ancient Art (1764), "les couleurs ne sont pas des sons" ("colours are not sounds," Euvres 1: 616-617). This was before literature, painting and sculpture were described in the $20^{\text {th }}$ century as different "semiotic" sign systems made up of words, sounds, paint or marble that cannot be easily substituted one for the other.

Since synesthesia mixes or combines the five senses, it may yet help bridge the gap between those systems. Ekphrasis itself is synesthetic, since it seeks to blend images with words and transmute sight or even touch into hearing - and sight as well, since the page and words can be seen. Thus, Shelley goes so far as to speak of a "translation" when he envisages the other way round, F.A.M. Retzch's illustration of the 1821 edition of Faust: "I fear it is the only sort of translation of which Faust is susceptible" (Letters 2:407, n697, to John Gisborne, 10 April 1822). Drawn lines and the sense of sight suggest Goethe's words, sounds and the sense of hearing, even better, Shelley claims, than English words and sounds can. What he also implies is that he draws similar delight from the senses of sight and hearing, as do Bacon and Madame de Staël, whose De L'Allemagne (1813) Shelley had also read:

Analogies among various elements of the physical world, serve to confirm the supreme law of creation, variety in unity, and unity in variety. What is more astonishing, for example, than the correspondence between sounds and forms, between sounds and colors? [...] We continually compare painting to music, and music to painting, because our feelings reveal analogies where cool observation would mark only dissimilarities. (qtd. in and trans. by O'Malley 18)

O'Malley does not study Shelley's ekphrasis or views on art, but he almost rewrites the poet's letter to John Gisborne when he says about a passage from "Orpheus" (1820), in which the poet seeks to

3 Such is Shelley's "Icarus complex," which partly consists in attempts at unity through the "synesthetic fusion of senses" (Bonnecase 6). 
"echo" Orpheus's "high song" and "picture forth his perfect attributes' with "words ne'er used before" (1. 98-102): "This suggests an odd refinement of ut pictura poesis: the orphic song, or poesis, can be represented (echoed) only by poesis which attempts to be picture" (150). Shelley indeed follows the Horatian tradition of Ut pictura poesis (Horace 480-481, 1. 361), which draws a parallel between the sister arts or "the sister-ladies, Painting and Music," to quote another of Shelley's influences, Erasmus Darwin. In "The Loves of Plants" (1789, "Interlude III"), later published in The Botanic Garden (1792), ${ }^{4}$ Darwin explains that the arts can "borrow metaphors from each other; musicians to speak of the brilliancy of sounds, and the light and shade of a concerto; and painters of the harmony of colours, and the tone of a picture" (Botanic Garden 2:180-181). This is what Shelley does, even in the few passages quoted above, in which statues "speak" and metaphors are described as "pictures of integral thoughts." Since "A Poet participates in the eternal, the infinite, and the one," he writes in "A Defence of Poetry," "as far as relates to his conceptions, [grammatical forms] are not" (Poetry and Prose 483). When Shelley therefore sees "relations" between sculptors, painters and poets in his long ekphrastic letter to Thomas Love Peacock of November 9, 1818 (Letters 2:53, n²86), he, like Bacon and de Staël, not only means a similar poetic impulse, but also the similar — poetic — "effect" produced by the different arts and the different senses of sight, hearing and touch:

For the Athenians employed language, action, music, painting, the dance, and religious institutions, to produce a common effect in the representation of the highest idealisms of passion and of power; each division in the art was made perfect in its kind by artists of the most consummate skill, and was disciplined into a beautiful proportion and unity one towards another. (Poetry and Prose 489)

The sister arts should be combined to produce a total poetic experience through what O'Malley calls "total synesthesia" $(34,92)$. This unity of the arts on the one hand and of the senses on the other makes both ekphrasis and synesthesia necessary and interdependent. At the same time, ekphrasis enables the poet to test the possibilities and shortcomings of synesthesia.

4 O'Malley (20-21) mentions this and another interlude in The Temple of Nature (1803, sec. 3 "Melody of Colours" of "Additional Note XVIII, Analysis of Taste"), and notes that Darwin refers to "Newton's computations for the spectrum-gamut parallel" and Bertrand Castel's colour organ experiment (also mentioned by John Locke). Shelley was thus aware of all of this. 


\section{Pictorialism as a necessary synesthetic transposition for ekphrasis}

Besides ekphrasis proper, synesthetic associations may be used as part of what James Heffernan calls "pictorialism" (3) and Mark Eigeldinger "art transposition" ("transposition d'art," 9099), poetry writing in the manner of a painter or sculptor or, to use O'Malley's phrase above, "poesis which attempts to be pictura." Just as some colours are "warm" or "cold," rhythm and the repetition of words or sounds may be substituted for colour and the painting brush, or stone and the striking chisel.

Pictorialism is naturally to be found in ekphrasis when the poet attempts to emulate the artist, but it can be found elsewhere in his work, as another way of writing poetry to give it a more visual dimension. Thus, certain passages in Shelley's "Prometheus Unbound" not only suggest the symphonies of Beethoven for certain critics (Zillman 52, n., 424) but also paintings, like the description of the Sphere of the Earth in act IV:

And from the other opening in the wood

Rushes, with loud and whirlwind harmony,

A sphere, which is as many thousand spheres,

Solid as crystal, yet through all its mass

Flow, as through empty space, music and light:

Ten thousand orbs involving and involved,

Purple and azure, white and green and golden,

Sphere within sphere; and every space between

Peopled with unimaginable shapes,

Such as ghosts dream dwell in the lampless deep,

Yet each inter-transpicuous; and they whirl

$[\ldots]$

Kindling with mingled sounds, and many tones,

Intelligible words and music wild.

With mighty whirl the multitudinous Orb

Grinds the bright brook into an azure mist

Of elemental subtlety, like light;

And the wild odour of the forest flowers,

The music of the living grass and air, The emerald light of leaf-entangled beams,

Round its intense, yet self-conflicting speed,

Seem kneaded into one aerial mass

Which drowns the sense. [...]. (IV, 236-261; The Poems 2:626-628) 
In the first part, the /o/ assonance and the $<_{0}>$ letter make the "opening" and spheres visible, even on the page; the $/ \mathrm{s} /$ and $/ 1 /$ alliterations on the one hand, and $/ \mathrm{p} /$ and $/ \mathrm{d} /$ on the other respectively suggest the movement of the Sphere and what hardness is necessary to give it tangible form; and the repetition of the words "sphere," "involve" and "through," like the repetition of notes or themes in music, makes the painting of words more musical. O'Malley (170) even goes so far as to see, line 242, "a verbal diagram of the spectral phenomena which [Shelley] so favors in his vision themes and their synesthetic expression." Although "the colors ranged in a single line appear in inverse order to the spectral red, orange, yellow, green, blue, indigo, and violet," the central "white" divides on either side into "purple," "azure," "green" and "golden," thus constituting a "stylized spectrum."

Here, only "kindling with mingled sounds" (1. 251), "the wild odour of forest flowers" (256) and "the music of the living grass and air" (257) are synesthesiae that respectively mix touch or sight ("kindling") and hearing ("sounds," "tones," "words," "music"); smell ("odour"), sight ("flowers") and even hearing (the /f/ alliteration, also suggestive of touch); and hearing ("music") and sight or touch ("grass" and "air"). Yet, the "kneading," line 260, and condensation of words referring to the senses in so limited space as those few lines, especially lines $256-258$, may also be described as synesthetic: the word-picture is colourful ("purple and azure, white and green and golden," "emerald light"), musical ("whirlwind harmony," "the music of the living grass"), fragrant ("wild odours") and tactile ("solid as crystal," "through," "grinds," "knead," /t/, /d/,/p/, /f/ alliterations). Besides the synesthetic crowding of words referring to the various senses, the "polysemy" of such words as "crystal" or "emerald" leads Shelley to deliberately associate touch and sight ("solid as crystal," "emerald light"), since they at once refer to their colour and solidity, as R. Fogle also remarks (see below). Besides, through this blending of sensations, Shelley's text emulates the immediacy or instantaneity of a visual work of art, beyond the limits of language, which is linear and thus subjected to time and a series of actions or sentences.

\section{The tangible and intangible: extension of the definition of synesthesia}

Shelley's poetry has often been described as "abstract," for instance by Mary Shelley in her "Note on the Prometheus Unbound" (1839):

More popular poets clothe the ideal with familiar and sensible imagery. Shelley loved to idealize the real - to gift the mechanism of the material universe with a soul and a voice, and to bestow such also on the most delicate and abstract emotions and thoughts of the mind. (Poetical Works 126, 127) 
A particular instance of this is the dematerialisation of Asia, Prometheus' ideal love, into shrouded light akin to the Shelleyan bodies through which the inner light of love shines:

Voice (in the air, singing)

Child of Light! thy limbs are burning

Through the vest which seems to hide them,

As the radiant lines of morning

Through the clouds ere they divide them;

And this atmosphere divinest

Shrouds thee wheresoe'er thou shinest. (II, v, 54-59, The Poems 2:572)

Shelley here seeks to give shape to the invisible aura of love felt beyond the sense of sight about the most beautiful shape or about the form of the beloved. To do so, he first dematerialises that shape, here the limbs, into light, which must be understood as intellectual or emotional rather than physical. In her German study on synesthesia, Erika von Erhardt-Siebold thus regrets Shelley's "costly disregard for concreteness" and that he "should [not] have modulated synesthetic language so as to preserve body and weight in sensuous intimations of a supersensuous One, not - as it happened - to etherealize them" (224-230, qtd. in O'Malley 10). Asia's transfiguration is still synesthetic, though, as the words used by the poet also excite the sense of touch ("burning") and evoke a Greek chiton or transparent "vest." Yet, what Shelley above all associates now are not so much the senses of touch and sight as these senses with something abstract and intangible.

The obverse is equally true, since Shelley likewise "loved" to solidify what is more or less intangible, like "abstract emotions and thoughts," but also the sky in "The Colosseum" (1818, "solid sky," first "liquid" and "flowing," Shelley's Prose 225-226), the air in "On the Medusa of Leonardo da Vinci" (1819, "the solid air," 1. 24, The Poems 3:222), water in "Lines written among the Euganean Hills" (1818, "Which her hoary sire now paves / With his blue and beaming waves," 98-99, 2:434) or mist in the same ("When a soft and purple mist / Like a vaporous amethyst, / Or an air-dissolvèd star / Mingling light and fragrance," 289-290, 2:440) and "Prometheus Unbound" ("As a grey and watery mist / Glows like solid amethyst," IV, 488-489, 2:643). Thus, R. Fogle notes that precious stones not only confer their colours but also their solidity to less tangible things, as does "crystal" and "emerald" in the Sphere of the Earth passage quoted above, 'a notable instance of the use of a tactual image to give body and firmness [...] with its suggestion of hardness in "emerald" (Imagery 68). This illustrates what he calls synesthetic "objectification" of more abstract things (125-126), like mist or thought. In his article on "Ozymandias" (1817), William Freedman (68) applies this to ekphrasis, when Shelley's reading of the Pharaoh's "passions" on the sculptured granite "physicaliz[es] spirit." 
When it comes to Shelley's poetry, the definition of synesthesia should therefore be extended to the associations of the tangible or sensuous and intangible or supersensuous, what Fogle calls the "instantaneous fusion of the concrete and abstract" (Imagery 101-102). Contrary to Keats's synesthesia, Shelley's intersense analogies are "likely to culminate in abstraction," are "symbolic, not naturalistic" and "less sensuous, and less spontaneous" $(123,127,122)$, as they "tended to reflect thought as opposed to sensation" (O’Malley 13). In other words, there are various degrees of synesthesia, from the actual blending of the senses to the mixture of sense with thought or ideas. Even O'Malley, who first seemed reluctant to broaden the definition of synesthesia, cannot help but equate Shelleyan synesthesia with the harmonisation of the sensuous with the supersensuous (163). Weighing the importance of abstraction against that of concreteness in Shelley's use of synesthesia, the critic, I think, successfully distinguishes between, and reconciles, the poet's natural bent and his more conscious effort:

I think his synesthetic practice does incline toward the abstract and toward heavy emphasis on light and sound. [...] [But] Shelley tried to compensate for abstract tendencies in synesthetic constructions, and to include within them data of the lowers senses [... although], even in such later poems [as Epipsychidion or Adonais], the balance seems to tip on the intellectual side [...]. (33-34)

This is exactly what happens to Shelley's ekphrases and transaesthetic allusions. While the evocation of colours, forms, material, weight, attitudes and gender makes his poetry more concrete and ballasts his "abstract imagination," it usually gives way to more abstract, invisible, transparent, disembodied, light or asexual forms: the two-sexed Borghese Sleeping Hermaphrodite (II ${ }^{\text {nd }}$ century A.D.) in the first draft of Epipsychidion is eventually replaced by the asexual "Seraphim" in the published poem, and the Christ-like Prometheus in act II of "Prometheus Unbound," partly modelled on Bolognese paintings, finally turns into a Turneresque vapour of light penetrating and possessing the spectator Panthea somewhat like Agathon's Eros does lovers in Plato's Symposium. Before Asia turned into a "Child of Light," she had also been described as a Sandro Botticelli's Venus Anadyomene (Birth of Venus, 1485). ${ }^{5}$

\section{Variety in unity: the metaphysical meaning of synesthesia}

The synesthetic associations in the picture of the Sphere of the Earth also "drown the senses" into one sea of sensations and ideas, since Shelley's synesthesia associates the sensuous and the

5 For O'Malley, however, this is part of the synesthetic complex of the poem that equates water with light figures, both being "Venusian" (156-157), i.e., from the irradiating Ideal. 
supersensuous and since the visual description also means something. In Richard Fogle's terms, when the critic comments on the description of Asia's soul as a concrete "enchanted boat" ("Prometheus Unbound," II, v, 72-110), there is a "synesthetic fusion of thought with sensation, and transferences among sensations themselves" ("Image and Imagelessness" 32-33). The passage is thus "a definite statement of the consummation towards which the Shelleyan synesthesia continually strives: a blending of all sensations into one mystical, ineffable, supersensuous harmony [...]" (Imagery 132) or "unity:"

Synaesthesia in Shelley is the poetical expression of a conscious, intellectual quest after a cosmic and psychic unity, in which the merging into Oneness of disparate physical phenomena symbolizes the ideal unity, in which the spirit strives. In the final stage of this process sense and spirit are themselves one, fused by intellect, sensation and emotion into an imaginative whole. (137-138)

Despite his greater emphasis on senses and sensations, O'Malley follows Fogle when he describes the Sphere of the Earth, "Shelley's best-known attempt to give an idea of ultimate unity through synesthetic expression" (169), as "a synesthetic ne[c] plus ultra" or "total synesthesia" showing the "unity in multiplicity" $(8,170-171)$, or when he concludes that

[This] merging into Oneness [...] obliterates ordinary distinctions between, for example, the sensory and the spiritual [...] because visionary synesthetic perception could be made to betoken spiritual elevation and order [...] so that synesthetic acuteness and the harmony of the sense reflect corresponding keenness and consonance of moral awareness. [...] [Shelley's] synesthesia involves a coordination, or even a fusion, of sensuous and spiritual experience. (176)

After Erika von Erhardt-Siebold, he also notes that synesthesia above all appears in Shelley's "ideal" or "visionary" verse (10), when the perception of a Power, the One or the Ideal is at hand: "first come crowded references to data of various senses considered separately, $[\ldots]$ then the suggestion is confirmed when the description culminates in synesthetic fusions" (9). Synesthesia is thus the "climactic expression[s] of sensuous harmony" (14), which is "at once sign and part of a greater harmony" (10). It is a potent trope to represent that ideal state of being beyond body and gender divisions, as in the ideal Hermaphrodite; to heal the divide between Man and Himself, Nature or Love, as in "Prometheus Unbound;" or to transcend the distinction between mind and external objects, as the poet writes in the essay “On Life" (1819):

The difference is merely nominal between those two classes of thought which are vulgarly distinguished by the names of ideas and of external objects. [...] The words, I, you, they, 
are not signs of any actual difference subsisting between the assemblage of thoughts thus indicated, but are merely marks employed to denote the different modifications of the one mind. (Poetry and Prose 477-478)

Among the "visionary rhymes" studied by O'Malley are "Alastor" (1815), Laon and Cythna or The Revolt of Islam (1817, 1818), "Prometheus Unbound," Epipsychidion, Adonais and The Triumph of Life, but I will only refer to passages referring to the visual arts, most of which are in prose. Bearing in mind those various implications of synesthesia - as a Shelleyan metaphor, as a means to regenerate figurative language and transcend conventions and aesthetic categories, as a necessary tool for pictorialism and ekphrasis, as an association of tangible and intangible forms, and as an embodiment of a monistic view of the universe - this study will now turn to Shelley's ekphrases of visual works of art and more particularly paintings.

\section{Synesthesia in Shelley's Ekphrases of Paintings}

In his ekphrases of Italian paintings in his letters, preface to The Cenci (1819) and poem "On the Medusa of Leonardo da Vinci" (1819), Shelley expresses a certain uneasiness about colour (Desset, "Colour"). ${ }^{7}$ Not that colours are absent from his poetry. Shelley definitely has his favourite hues, which are usually symbolic of certain states of mind or ideas. Through a metonymy with the bright serene sky or sea, for instance, Italy but also spring and June are described as "azure," and like gold, azure usually refers to positive feelings or states, like "smiles" in "Alastor" $(1815,1.491)$, "mirth' in "To Jane. The Invitation" $(1822,11)$ or "calm" in "Prometheus Unbound" (III, ii, 42). These associations of colours and intangible emotions or thoughts objectify the latter synesthetically. The last example, "azure calm," and "Killing the azure silence" ("Ginevra," 1821, 1. 43) even mix sight and hearing, because in Shelley's poetry azure is also the colour of night, when all is silent and serene. There is a similitude between azure and silence, and the synesthesia "azure silence" or "calm" is therefore synonymous of "serenity."

6 "the different modifications of the one mind" echoes one of Shelley's lecturers at Syon House Academy and Eton, Adam Walker, for whom "All our senses may be said to be modifications of the sense of feeling" (2:90, qtd. in O’Malley, 22).

7 Frederic S. Colwell ("Italian Painting" 59) speaks of "a preoccupation [...] an often self-conscious concern with colour," which, I think, must be understood as difficulty rather than interest, as the poet "centers upon the painter's handling of light" and shade instead, as I have shown in my article. 


\section{Antonio Allegri Correggio's Saviour (ca. 1525): the harmony of dissolution}

In ekphrasis, however, Shelley seems more uneasy with colour, although Italian paintings force him to confront that uneasiness and even test new tints, beginning with a "Christ beatified" by Correggio (Colwell, "Italian Painting" 56, fig.2):

It is a half figure rising from a mass of clouds tinged with an ethereal rose-like lustre, the arms are expanded, the whole figure seems dilated with expression, the countenance is heavy as it were with the weight of the rapture of the spirit, the lips parted but scarcely parted with the breath of intense but regulated passion, the eyes are calm and benignant, the whole features harmonized in majesty \& sweetness. The hair is parted on the forehead, and falls in heavy locks on each side. It is motionless, but seems as if the faintest breath would move it. The colouring, I suppose must be very good if I can remark \& understand it. The sky is a pale and aerial orange like the tints of latest sunset; it does not seem painted around \& beyond the figure, but every thing seems to have absorbed, \& to have been penetrated by its hues. (Letters 2:49-50)

The repetition of the verb "seems," the phrases "as it were" or "as if," which can be found in other ekphrases, the similes and the hesitation about "the colouring," although the poet mentions a "roselike lustre" and the more obvious "pale and aerial orange," give scope for "unapprehended relations of things" and thus synesthesia: "the whole features harmonized in majesty \& sweetness" first mixes painted lines and music, sight and hearing, since it is by analogy only that "harmony" now refers to visual unity and balance. Although O'Malley does not mention Pliny's Natural History (XXXV, xixii, 9:282-283), ${ }^{8}$ Shelley may think of harmogen (Desset, "Palimpseste plinien" 90), which refers to the "attunement" and progressive blending of "sombre" and "brilliant" colours. Indeed, "everything seems $[\ldots]$ to have been penetrated by [the sky's] hues." When Shelley used the words "harmony" and "harmonize," it had thus already become a dead synesthesia for colours and forms, even though Madame de Staël's use of the word harmony for colours also suggests that it was not necessarily perceived as such: "[...] sounds act like colors; colors melt into harmony" (Corinne ou l'Italie [1807], qtd. in and trans. by O'Malley 95). Shelley first foray into pictorial ekphrasis recalls his poetic juvenilia, in which more or less common place synesthesiae are to be found. Actually, Shelley had already used the word "harmony" and even "unison" to refer to colours in The Retrospect:

8 In fact he does mention Pliny, but only the passage from "De deo" (Natural History, Bk. II, ch. v) which Shelley quotes in the note to Queen Mab, VII, 13 ("There is no God"). Pliny describes God as consisting "wholly of sense, sight and hearing, wholly of soul, wholly of mind, wholly of himself" (1:179). O'Malley (41) quotes this for the opening of part VI, in which Ianthe is "All touch, all eye, all ear" (The Poems 1:320) and "reflects the colors of Mab's speech," although he actually thinks that Paradise Lost (1667, VI, 344-351) is a better source. 
With that same scene when peaceful love

Flings rapture's colours o'er the grove

When mountain, meadow, wood and stream

With unalloying glory gleam

And to the spirit's ear and eye

Are unison and harmony. (17-22, The Poems 1:222)

Yet, as O'Malley notes, even Shelley's common place synesthesiae can develop into more complex intersense analogies in his later poems. In "Hymn to Intellectual Beauty" (1816), for instance, the poet writes about the "hues and harmonies of evening" and "a harmony / In Autumn, and a lustre in the sky / Which through the summer is not heard or seen" $(8,74-76$, The Poems 1:525, 527), although colours and sounds are more coordinated here than mixed. In Epipsychidion, eloquent eyes or "looks" also "Harmoniz[e] silence without a sound" (560-564, Poetry and Prose 387), even though this harmony is more intellectual than aural or visual.

O'Malley, therefore, does not consider the verb "harmonize" as a dead synesthesia when he analyses "thy dear eyes / Shone through my sleep, and did that utterance harmonize" in Laon and Cythna (VII, xxxii, 6-9 [3116-17], The Poems 2: 191):

"Harmonize" may often have very general significance, of course, but here it synesthetically keys a complex expression. In view of Laon's role as [Venus-like] Lucifer and Cythna's mention of Crotona, where Pythagoras reputedly taught, "harmonize" probably refers to spheral music, which was supposed to "attune" virtuous spirits. Light from Laon-Lucifer's eyes, especially since it harmonizes a love song, can readily be associated with the light of Venus. Cythna's song, then, has been attuned to a "melody of light," Shelley's synesthetic equivalent of spheral music. (66)

Correggio's Saviour is also a melody of light, since his harmonious colours are refracted light, a Pythagorean music of Venus, but not only.

The phrase 'the whole features harmonized in majesty \& sweetness' also transfers the contrast between light and shade, which Shelley finds elsewhere in the painting ("lustre" / "cloud") and which Pliny calls tonon and the Italian Renaissance chiaroscuro, onto an intellectual plane. It above all refers to the contrast between subject and execution, which Winckelmann praises in Greek sculpture, as opposed to modern painting (Reflections 32-33, where the term "contrast," however, means excess and the absence of aesthetic temperance). Praxiteles in particular, the representative of the Beautiful style 
(Euvres 2:2,67), knew how to temper the sublime with softness, or the Uranian Grace with the earthly one, in his representations of gods and goddesses. As a matter of fact, Shelley's "harmony" does not so much refer to colours, as to sublime "majesty" and the softer "sweetness," which, while they are visual (the roundness of Christ's forms, his calm, seated attitude), above all represent feelings, values and ideas. The verb "harmonize" is thus synesthetic in the broadest sense of the term, since it associates forms and ideas, and as in The Retrospect and Epipsychidion, the harmony is intellectual. Hearing, however, is not totally absent, since Shelley can hear "the breath of intense but regulated passion," yet another instance of Winckelmannian temperance of excess. That Shelley remembers the musical dimension of "harmony" will be verified in "On the Medusa of Leonardo da Vinci."

Still, synesthetic objectification of intangible things is what prevails in the letter. Admittedly, the representation of "a mass of clouds," "sky" and "lustre" on solid canvas already makes them more tangible, but in the text, the painted "figure' is also "dilated with expression," while the "countenance" is "heavy as it were with the weight of the rapture of the spirit." Moreover, the verb "dilated," maybe suggested by the round pupils and expanding arms and halo of light, the adjective "heavy" and the noun "weight" at once suggest the senses of sight and touch, just as the "calm eyes" and "parted lips" waver between silence and "expression," thus mixing sight and hearing. The polysemous adjective "heavy," however, means "drowsy" here, like Peter "heavy with sleep" in St Luke (ix. 32), yet the polysemy remains. This association, on the one hand, of sight, touch and hearing, and on the other, of senses, emotions and ideas, which are also Shelley's projected impressions, since the dilated eye may refer to him too as a spectator, help the poet "express" those impressions and bridge the gap between his words and the visual representation.

These associations also disintegrate or dissolve the picture into something less tangible, just as the "mass of clouds" of which Shelley speaks replaces the white drapery on the painting from which the supposedly "half-figure" actually emerges. . Although they above all refer to the tints of the sky at dawn and dusk, the adjectives "ethereal" and "aerial" make the colours "pink" and "orange" more transparent. The last sentence highlights that dissolution: "every thing seems to have absorbed, \& to have been penetrated by" the hues of the sky. As Teddi Bonca (188) also notices, through the technique

9 Curiously, Shelley seems to have only seen the upper part of the picture, which would account for his mistaking the drapery for clouds, his reduction of the picture to a "half-figure" and the absence of the four putti. Shelley may also conflate this Christ with one by Franceschini in his "Assumption of Saint Catherine" on the vault of the Corpus Domini (Colwell, "Italian Painting" fig. 4), now destroyed, in which Christ rises from clouds, has expanded arms and dissolves into light. Teddi Bonca (189), however, claims that that lower part of the painting influenced the description of Asia as a Venus Anadyomene standing in a shell (II.v.54). 
of sfumato, of which Correggio was actually a master, the figure has become as ethereal as the sky, an ideal unity or supersensuous harmony has been rendered, and colours and forms can no longer be distinguished. As Frederic Colwell notes ${ }^{10}$ it is exactly what happens to Prometheus in Panthea's dream. The scene draws on previous poems ${ }^{11}$ as well as on that ekphrasis and Guido Reni's Crucifixion of the Capuchins (Colwell, "Figures" 120, fig. 1), which provides the Titan with his "wound-worn limbs" and "passion-parted lips:"

$[\ldots]$ his pale, wound-worn limbs

Fell from Prometheus, and the azure night

Grew radiant with the glory of that form

Which lives unchanged within, and his voice fell

Like music which makes giddy the dim brain,

Faint with intoxication of keen joy:

[...]

I lifted them [my eyes]: the overpowering light

Of that immortal shape was shadowed o'er

By love; which, from his soft and flowing limbs,

And passion-parted lips, and keen, faint eyes,

Steamed forth like vaporous fire; an atmosphere

Which wrapped me in its all-dissolving power,

As the warm ether of the morning sun

Wraps ere it drinks some cloud of wandering dew.

I saw not, heard not, moved not, only felt

His presence flow and mingle through my blood

10 Although he does not refer specifically to Correggio's Christ: "The aerial forms which Shelley praised in Bologna, particularly in the Franceschini frescoes in the soffit and dome of the Church of Corpus Domini, [...] the evanescent forms dissolving and materializing in universal light contributed those qualities that make Shelley's rendering of the Prometheus drama wholly unique in its imagery and realization" ("Italian Painting" 66).

11 Prototypes of the shadowing light bursting from Prometheus, in glory as Christ in the same passage of St Luke (ix. 32), of his parted lips and even of the "rose-like lustre" in the painting can already be found in The Revolt of Islam (I, lvii, 634-635: "The radiance of whose limbs rose-like and warm / Flowed forth, and did with softest light inform / The shadowy dome, the sculptures [...];" XI, v, 4261-4269: "Her lips were parted, and the measured breath / Was now heard [...]," "Absorbed the glories of the burning skies, [...] mingling with her heart's deep ecstasies, / Burst from her looks [...] a light / Of liquid tenderness like love," "its beams, tremulous and soft and bright," The Poems 2: 92, 238). The image will be found again in Epipsychidion (77-82, Zillman 425-426). 
Till it became his life, and his grew mine,

And I was thus absorbed. [...]. (II, i, 62-82, The Poems 2: 530-31) $)^{12}$

The concrete elements of the two paintings and Winckelmann's Beautiful style (the "azure sky," "soft and flowing limbs," "passion-parted lips") give way to "vaporous fire" and an invisible "overpowering light," not unlike the painting's "radian[ce]" and "glory" (to use the poem's terms). It "penetrates" and "absorbs" the spectator Panthea, just as the rose-like and orange sky do Christ. In the poem, colours merge back into the original white light of the One, while subject and object are also made one - it was latent in the letter, as the "dilated eyes" suggested. This disintegration (or reintegration) is also dramatic, as the spectator Panthea plays the part of an intermediary between Prometheus, in act I, and Asia, in act II. She must therefore embody and "carry" the beloved or ideal love.

The synesthetic blending of sight ("pale," "radiant," "light") and touch ("fire," "wrapped," "felt... through my blood") again serves to represent that invisible mystic light of love ("I saw not"), which, as in Winckelmann's Beautiful style and Shelley's letter, tempers the sublime appearance of the Titan ("overpowering light;" "shadowed o'er / By love"). This contrast between fire and softness, and between light and shadow, also evokes Pliny's harmogen or tonon and the Italian chiaroscuro. The presence of music suggests that the harmony of the letter was also musical: Prometheus "faint with intoxication" recalls Christ "heavy with the weight of the rapture," while the Titan's "passion-parted lips" and "voice f[alling] / Like music" echoes Jesus's "lips parted but scarcely parted with the breath of intense but regulated passion," in which "passion" is also polysemous. The sense of taste is even suggested in the poem by "faint with intoxication" and "the warm ether of the morning sun [...] drinks some [...] dew," which, besides, mixes touch ("warm," "dew”) and sight ("sun"). By fusing the senses together or dissolving them ("I saw not, only felt"), as in the Sphere of the Earth, Shelley describes another mode of experience and another state of existence. He also turns the experience of art into a mystic one.

12 D. Bush (159, n. 33) and Carlos Baker (103, n. 33) were among the first to suggest Correggio's Christ, after Arthur M.D. Hughes and Walter E. Peck, in their respective editions of Shelley's poems, and Ilsa O'Sullivan-Köhling (157), whom Bush actually quotes. However, Shelley already conflates the two paintings in the letter, as the parted lips can only be seen in Guido's Christ, unless the poet in fact describes another Correggio's or a misattributed Christ. Similarly, "his... limbs / Fell from Prometheus," which has been variously interpreted, even literally, suggests Guido's crucified Jesus, whose arms are indeed "pale," "wound-worn" and exhausted, as opposed to the round, wholesome "expanded" arms of Correggio's Christ. Therefore, "falling" may actually mean "freed," that is to say, departing from the horizontal, since Prometheus is in the process of being freed. 


\section{Guido's Fortune Restrained by Love (1637): from Urania to Pandemos}

\section{Shelley uses another synesthesia to describe Guido's Fortuna:}

There was the figure of Fortune on a globe eagerly proceeding forwards and Love was trying to catch her by the hair and her face was half turned towards him, her long chestnut hair was floating in the stream of the wind and threw its shadow over her fair forehead. Her hazel eyes were fixed on her pursuer with a meaning look of playfulness and a light smile was hovering on her lips. The colours which arrayed her delicate limbs were ethereal \& warm.

"Warm colours" is again a dead synesthesia, but Shelley develops and regenerates it: the warm colours of Fortune's rose-like skin, "chestnut" hair and "hazel" eyes are also "ethereal," which refers to something intangible, like the blue sky round her. For Shelley, indeed, blue is not necessarily a "cold colour," as it evokes June and the warm climate of Italy and since "azure" or "blue" glows can sometimes be found in his poetry. Here, Shelley metonymically transfers the adjective "ethereal" from the azure, serene background to Fortune's skin, but it is less the colour than the intangibility of the sky that penetrates and absorbs her, as the orange sky did Christ. At the same time, the verb "arrayed" seems to solidify these "ethereal and warm" colours by turning them into drapery or a chiton through which Fortune's naked body can now be seen. However, this concretisation is an illusion: Fortune's limbs, like Asia's, when she is described as a "Child of Light," dissolve into an intangible transparent vest letting the inner light, the soul of beauty, through, all the more so as the verb "arrayed" contains the word "ray."

Shelley also suggests the sense of taste when he chooses the adjectives "chestnut" and "hazel" over the vaguer "brown" or "dark" to describe her hair and eyes: $:^{13}$ this is an erotic scene, since it represents Eros chasing a naked Venus-like Fortune, and the synesthetic allusions to sight and taste, however common-place "chestnut hair" and "hazel eyes" are, express erotic delight. There is a similar eroticism in the sun-dew simile of "Prometheus Unbound," in which the sun-like Prometheus drinks the dew-like Panthea even to "intoxication." 14 The sense of touch is also excited by the verbs of "catch by the hair," "floating in the stream of the wind," which is made a little more tangible than air, "threw its shadow over her fair forehead," which also suggests chiaroscuro, "fixed on her pursuer" and, above

13 It is possible to agree both with Oscar Firkins (136), when he says that Shelley associates the senses in their simplest, less differentiated forms, like "sound, and odour, and beam" in The Sensitive Plant (1:92) or dark eyes and fair hair in characterisation, and with Fogle, when he notes the poet's "exquisite feeling for subtle gradations of coloring, changes of sensuous tone, degrees of relationship in sensation" (Imagery 136-137).

14 Contrary to what Fogle says (Imagery 90), Shelley's "infrequent gustatory images" are not always "disagreeable." 
all, "a light smile was hovering on her lips:" the polysemous adjective "light" echoes the polysemous adjective "heavy" of the previous paintings, and thanks to the preposition "on" pleasure is made as tangible as death lying "as heavy as sleep" on, and "pain passing from," the Philistine's lips and head in the ekphrasis of Guido's Triumph of Samson (1611-1612). Shelley therefore does not only dissolve the body; he also objectifies emotions and abstract things.

\section{Guido Reni's Madonna with Child (1628-1630): objectification and ventriloquism}

Guido's "Madonna lattante" (Colwell, "Italian Painting" 54, Fig 1), which appears to be Shelley's favourite in the letter, must have reminded him of his own Mary breastfeeding his daughter Clara, who had died less than two months before:

She is leaning over a child, and the maternal feelings with which she is pervaded are shadowed forth on her soft \& gentle countenance and in her simple and affectionate gestures. There is what an unfeeling observer would call a dulness $[$ sic $]$ in the expression of her face. Her eyes are almost closed, her lips deprest; there is a serious and even a heavy relaxation as it were of all the muscles which are called into action by ordinary emotions. But it is only as if the spirit of a love almost insupportable from its intensity were brooding upon and weighing down the soul, or whatever it is without which the material frame is inanimate and inexpressive. (Letters 2:51)

"A love almost insupportable" really sounds like a projection of Shelley's feeling at the death of Clara onto a picture which, on the contrary, is about giving life. The poet thus repaints the picture, replacing all the colours by darker tones ("shadowed," "dullness"), and conveys an almost negative vision of love, when tragic events make it painful.

Yet, the Madonna's "intense," "shadowed forth" maternal love also announces Prometheus's "overpowering light [...] shadowed o'er / By love," so that the Titan of the poem is likened to the Virgin Mary, although in the painting, the light also seems to come from the infant Christ or from above. The phrase "shadowed o'er by love" is at first sight paradoxical or oxymoronic, like Milton's "darkness visible," since love is usually described as something luminous in Shelley's poetry, like the sun in Epipsychidion. The sun, however, casts shadows, and so does Prometheus's love, thus tempering his titanic "overpowering light" with milder, more earthly shadows. In the painting, the "shadowed forth" "maternal" love is even more oxymoronic, as love not only casts shadows but is itself described as a shadow: Shelley in fact refers to the brightness of Mary's face, but the shadows on her neck, cheek, eyelids and beneath her nose and lower lip also temper that brightness. The result is thus the same in the two word-pictures: those shadows are symbolic of human "feelings," beautiful ones that 
is, that make the "overpowering" or "intense" divine Ideal (Beauty, Truth or pure Love) perceptible. Again, encouraged by the contrast between the dark background and the white skin of the infant, the poet favours chiaroscuro over the dark red and blue colours of the Madonna's drapery, but indirectly, through the contrast between the noun "intensity," suggesting a dazzling light, and the verbs "brooding upon and weighing down" referring to "the spirit of love" covering the soul, like dark, looming clouds.

The poet also resorts to synesthetic objectification, as his now familiar reference to weight and polysemous heaviness suggest sadness more than the actual drowsiness of the picture, even though the poet also mentions her "eyes... almost closed." This heaviness weighs down, as it were, the picture, and makes the sadness projected onto it more tangible. Feelings are objectified or personified, like "maternal affection" and "the spirit of love," which animate the "gestures" and "muscles called into action." Stephen Cheeke (10, n. 39) notices a similar "animism" in Shelley's "Notes on Sculptures," like "the filial love and devotion that animates" the sons of Laocoön or "the intense energy and godlike animation of th[e] limbs" of "Another Apollo" (n² and 27 or 26, Shelley's Prose 344 and 347). The "maternal affection" and "spirit of love" also make those gestures speak, an instance of ekphrastic prosopopeia, to use James Heffernan's term in A Museum of Words (6), or rather ventriloquism, since it is not only the spirit of love but the poet who makes what he deems "inexpressive," "the [visible] material frame," expressive. Yet, more than prosopopeia or ventriloquism, it is the association of intangible feelings, sadness and love, with the sense of touch, which is synesthetic. Like Samson "standing in strong relief" a page before, it also likens the painting to a sculpture. The adjectives "soft \& gentle," "simple" and "inanimate" indeed recall Winckelmann's Beautiful style and description of "The Niobe" (1:424-425), in which pain is tempered, restrained or "swallowed up," to use Shelley's translation in his "Notes on Sculptures" (Shelley's Prose 353) of the French concentré in L'Histoire de l'art chez les Anciens (Euvres 2:33).

Shelley might well have used that painting for the description of Asia and her son, the Spirit of the Earth, in the third act of "Prometheus Unbound." Although the passage does not really echo the ekphrasis, in which light is like a shadow and not liquid like milk, there is an allusion to breastfeeding in the doubly synesthetic (taste, touch, sight) "[...] to drink the liquid light / Out of her eyes," III, iv, 17-18, The Poems 2:599). It is actually easy to understand, when we look at the painting, why Shelley replaces the breast by the eyes and thus resorts to synesthesia: the bambino at once seems to drink his mother's milk with his mouth and her love with his eyes. This emphasis or revaluation of sight is also found in "May I then hide my eyes in thy soft arms, / After thy looks have made them tired of joy?" (26-27), but joy here has overwhelmed sadness. 


\section{Marcantonio Franceschini's Putti and serene skies: synesthetic balance and harmony}

Marcantonio Franceschini's "winged children" and breastfed infants may also have served as models for the Eros-like Spirit of the Earth who asks Asia to "play beside [her] the long noons / When work is none in the bright silent air" (28-29). In his two Charities (Carità, 1641 and ca. 1680), which Shelley does not mention though, a woman is for instance represented breastfeeding one of her three children or playing with them or doing both at once:

The colouring of his pictures is less warm than that of Guido, but nothing can be more clear \& delicate. It is as if he could have dipped his pencil in the hues of some serenest \& star-shining twilight. His forms have the same delicacy, and aerial loveliness. Their eyes are all bright with innocence and love, their lips scarce divided by some gentle and sweet emotion - his winged children are the loveliest ideal beings ever created by the human mind. These are generally (whether in the capacity of Cherubims or Cupids) accessories to the rest of his pictures which are all on sacred subjects, \& the under plot of their lovely and infantine play is something almost pathetic from its excess of unpretending beauty.

The "pathetic," which predominates in Shelley's pictorial ekphrases and, like the words "delicate" and "delicacy," characterises ancient paintings in the poet's "Discourse on the Manners of the Ancient Greeks" (1818, Notopoulos 404), is again related to the "excess" of innocent beauty and "infantine play." As in the "Madonna lattante," the ekphrasis is oxymoronic, since "excess" and "unpretending" on the one hand, and "pathetic" and "beauty" or "lovely and infantine play" on the other, are usually barely reconcilable. While this painful beauty may be accounted for by the Shelleys' recent loss, it is as though he had once again to temper love, beauty and playfulness with pathos to reach a certain balance, or for ideal love and beauty to be experienced by the human senses.

Since he compares Franceschini with Guido, whose Madonna lattante he has just described, the poet again resorts to the "warm colour" dead synesthesia, which he regenerates this time by developing it into the surrealistic "dipped the pencil in the hues of some serenest \& star-shining twilight." 15

15 There are not any stars in the serene blue skies of the paintings I have seen, including the Annunciation (Annunciazione, 1700 in Cesena or 1726 in Bologna) which Mary describes in the same letter, even though Franceschini paints dawn and night skies. The "star-shining twilight" may only be a metaphor, unless it could be seen on the walls and vault of the church of Corpus Domini, destroyed in 1943. F.S. Colwell claims that Mary actually refers to the Ascension of La Santa (Assunzione, 1688-1694) painted there or "assumption of Saint Catherine in a glory with many angels, saints, and allegorical figures" ("Italian Painting" 59, fig. 4), but Mary's depiction ("The angel is beaming in beauty — The Virgin soft retiring \& simple") may as well suggest the Annunciation in Cesena. 
The colour alluded is (dark) azure, symbolic of serenity, but the expression is both oxymoronic and synesthetic: Shelley mixes water ("dipped") with fire ("star"), touch (“dipped") with sight ("hues"), and the tangible ("pencil") with the intangible ("twilight"). The "star-shining twilight," like Milton's oxymoron, also combines light and shade. The phrase "aerial loveliness" again dissolves those forms into thin air, since Shelley deals with "ideal beings," that is to say fantastic creatures or personified ideas. At the same time "innocence and love" and "gentle and sweet emotion" are objectified by the "eyes" and "scarce[ly]" parted lips, which Shelley again causes to speak. Indeed, the reverse effect of ekphrastic prosopopeia is that the emotions "expressed" by the painted forms are embodied in the lips, eyes and other body parts mentioned by Shelley and thus become tangible: "innocence and love" and "gentle and sweet emotion" can almost be touched.

\section{Raphael's Ecstasy of St Cecilia (1514-1516)}

Another favourite of Shelley's is The Ecstasy of St Cecilia (Estasi di Santa Cecilia) ${ }^{16}$ whose subject already marries music and painting:

$[\mathrm{T}]$ his is in another and higher style. You forget that it is a picture as you look at it, and yet it is most unlike any of those things which we call reality. It is of the inspired and ideal kind, and seems to have been conceived \& executed in a similar state of feeling to that which produced among the antients those perfect specimens of poetry \& sculpture which are the baffling models of suc[c]eeding generations. There is a unity \& perfection in it of an incommunicable kind. The central figure St. Caecilia seems rapt in such inspiration as produced her image in the painters mind, her deep dark eloquent eyes lifted up, her chestnut hair flung back from her forehead, one hand upon her bosom, her countenance as it were calmed by the depth of its passion \& rapture, \& penetrated throughout with the warm \& radiant light of life. She is listening to the music of Heaven, \& I imagine has just ceased to sing for the three figures that surround her evidently point by their attitudes towards [her], particularly St. John who with a tender yet impassioned gesture bends his countenance towards her, languid with the depth of his emotion. At her feet lie instruments of music broken \& unstrung. Of the colouring I do not speak, it eclipses nature, yet it has all its truth \& softness. (Letters 2:51-52)

16 In the painting reproduced in Anna Benneson MacMahan 62, St John's "countenance" is bent towards the "unstrung" instruments and not towards Cecilia; she is surrounded by four, not three figures, and none "evidently" points towards her; her hand is not on her bosom, since she holds large panpipes with both hands; it is the lady behind her who is in that attitude; and Cecilia's hair is not flung back like Fortune's but tied in a turban with a knot. Could Shelley have once more conflated two paintings? 
Music, however, is suggested by the "unstrung" instruments, and Cecilia, who "has just ceased to sing." This is typical of Shelley's "abstract imagination:" rather than evoking music, he prefers to conjure up the memory of it, as O'Malley notes when he writes that light and sounds in Shelley's synesthesia are all the more abstract or remote as they are respectively "mirrored (by moon or streams, for example), veiled (by clouds or mist), or refracted (in water spray)," and described as "sounds that, analogously though even more elusively, echo a pure harmony (as in memory) or attenuate it" (38). Memory further disembodies that music and removes it from the material, phenomenal world. Shelley reproduces the silence of a painting and the pregnant moment in Raphael's picture, since the music is only heard in the poet's mind and he does not seem to be willing to indulge in ventriloquism.

This is a false impression again. To start with, the prefix un- at once implies absence or destruction and potentiality. Likewise, the participle "broken," which, in the sequence of "At her feet lie instruments of music broken," may be polysemous and mean that "music" has "come into being" $\left(O A L D\right.$, def. $\left.\mathrm{n}^{\circ} 9\right)$, like dawn or a storm. Obviously, Cecilia's voice has also been "broken" or cut short by the angels" "music of Heaven," which she is now "listening" to. This Pythagorean music of the spheres, however, is intangible as it can only be heard in the mind and not through the ears, in an oxymoronic way, like "darkness visible." For O'Malley, it is yet synesthetic, as the crystalline planets' and Venus's lights are "synesthetically audible": their "ethereal harmony [is] perceptibly radiant" and "symbolise[s] the rare spiritual elevation needed to hear this mystical harmony" (59-60). The painting's colours thus embody that music, as, in The Triumph of Life (478-479), "The world can hear not the sweet notes that move / The sphere whose light is melody to lovers" (Poetry and Prose 468). Had he studied this ekphrasis, O’Malley (94) would have described as synesthetic Spheres or Venuses the painting's "heavens" and colours, and Cecilia who may be described as an "embodied Ray / Of that great brightness" ("Fragments connected with Epipsychidion" 38-39, Complete Poetical Works 426), since she is made of colours. However remote the music of the heavens, instruments or Cecilia's voice is, it is heard by the painter, poet and reader.

Shelley also uses ekphrastic ventriloquism to make the picture speak and reveal the "feeling" and "inspiration" behind the creation of the work of art, as well as the "passion" and "languidness" which animate St John's and Cecilia's countenances. Her eyes are indeed "eloquent," another dead synesthesia or "commonplace" that O'Malley (24) finds in Shelley's juvenilia, for instance in "'How eloquent are eyes!"” (1810, The Poems 1:91, 1. 1) There is therefore a balance between silence and voices, although Shelley also speaks of an "uncommunicable" unity — yet note the prefix. ${ }^{17}$ Still, we

17 He again uses this adjective in the preface to "Prometheus Unbound:" "[T]he [form] is the endowment of the age in which they live, and the [spirit] must be the uncommunicated lightning of their own mind" (The Poems 2:473-474). 
understand, nous entendons what Shelley means by "unity:" it is formal, since the saints around Cecilia form a circle and direct the reader's gaze towards its centre; it is also conceptual, even metaphysical, as Raphael and Cecilia, not to mention the spectator, Shelley, join into a common feeling, inspiration.

There is another contradictory movement in this ekphrasis. Following Pliny's taste for naturalism ("radiant light of life," "all [the] truth and softness" of nature), Shelley ceases to consider the painting as such ("You forget that it is a picture") so as to refer to the figures as real people whom he can describe directly: he has entered the diegesis or it is they who have "walked forth among their worshippers," as he says of the statues of the Muses and Apollo in "A Defence of Poetry" (Poetry and Prose 497). At the same time, he dematerialises the painting into something "unlike... reality," of "an ideal kind," like Franceschini's putti. The last remark about "the colouring" thus removes ("eclipses") the representation from the realm of painting and "nature" to the world of abstract ideal forms. This contradictory movement once more creates a Winckelmannian balance, which the conjunction "yet" epitomizes: in the last sentence about the "truth and softness" of the colouring and nature, abstract "truth" is synesthetically associated with tangible "softness."

Similarly, in an attempt to ballast his abstract imagination, the earthly colour of the "chestnut" hair is combined with an earthly, tangible chiaroscuro ("deep dark... eyes" / "warm \& radiant light of life"), which, however, Shelley again substitutes for the other colours of the painting. The darker chestnut hue itself contributes to this chiaroscuro, as "her chestnut hair flung back from her forehead" also suggests a broad, paler brow. Finally, the association of the words "penetrated" and "light," and, to a certain extent, "depth" and "passion," is synesthetic, as touch is mingled with sight or emotions. These dead metaphors of penetrating light and depth of passion make the description somewhat sensuous, although only the chestnut colours may suggest taste, as in Guido's erotic chase, and Shelley does not use the image of "drink." Yet, the word "rapt" is redoubled by the word "rapture," so that what the poet describes here is a Christian version of Dionysian "inspiration."

The comparison with ancient art, probably encouraged by the white folds of the woman's drapery on the right-hand side, also removes the Renaissance painting to a more distant and ideal past, and partly turns it into a statue. Timothy Webb (153) compares Shelley's remark in Hellas (1820), "The human form and the human mind attained to a perfection in Greece which has impressed its image on those faultless productions, whose very fragments are the despair of modern art" (Poetry and Prose 409) to Fuseli's picture of "The Artist in Despair Before the Grandeur of Antique Fragments" (17781779). In Shelley's ekphrasis, the phrase "baffling models of succeeding generations" also evokes Fuseli, which contributes to turning Raphael's painting into a sculptural fragment. Shelley's use of 
Winckelmann's aesthetic discourse, as Frederic Colwell notices ("Italian Painting" 51), although the critic only mentions the vaguer notions of "ideal beauty," "unity and perfection," suggests the Beautiful style in sculpture, which Shelley calls "a higher style" here, particularly the contrast between the words "divine" and "softness," or the temperance in the Christ-like "calmed by the depth of its passion and rapture" and "tender yet impassioned."

\section{Other Italian paintings: erotic balance}

Following the ekphrasis of the sketch of Michelangelo's "Last Judgment" (1535-1541) in the letter of the 25 February 1819 to T.L. Peacock, Shelley gives short descriptions of interest for this study:

The other paintings are one or two of Raphael, or his pupils very sweet \& lovely. A Danae of Titian, and a picture [of] the softest \& most voluptuous form with languid \& uplifted eyes \& warm yet passive limbs. A Maddelena by Guido with dark brown hair \& dark brown eyes and an earnest soft melancholy look. (Letters 2:81, n $^{\circ} 492$ )

Whereas "sweet \& lovely" does not necessarily mix the senses of taste or touch and sight, "the softest $\&$ most voluptuous form" and "warm yet passive limbs" definitely suggest the sense of touch and the obvious eroticism of a naked Danae. Shelley seems to touch the "voluptuous form" beyond the coldness of the canvas, but he also tempers ("yet") that eroticism by conjuring Niobe's "passive" temperance as described by Winckelmann and by transferring, so it seems, Magdalena's "uplifted eyes, "symbolic of divine inspiration, not unlike St Cecilia's, to Danae. Magdalena's "soft melancholy" also blends sensation with emotion, which is made more tangible, while it expresses a certain balance between the two extremes of pleasure and despair. Finally, in the sequence of the letter, those short ekphrases temper the darkness and lack of balance in "The Last Judgment."

\section{7. 'On the Medusa of Leonardo': oxymoronic synesthetic associations}

"On the Medusa of Leonardo" (The Poems 3:221-223) is the poet's only verse ekphrasis of a painting, if we except the rewriting of the Bolognese letter in "Prometheus Unbound" and later poems or "At the Creation of the Earth [The Birth of Pleasure]" (1819), which partly draws on Botticelli's "Birth of Venus." Since I have already talked about colour (Desset, "Colour" 177-186), I will only focus on what is synesthetic, as, more than ever, Shelley struggles to translate "The Head of Medusa" (ca. 1600) into words. 
Despite the lack of colours, for which Shelley substitutes light and shade, the emphasis on the visual aspect of the painting is a first step towards pictorialism. The sense of sight is excited by the semantic accumulation of words like "eyes" $(5,15,26)$ and "gazes" $(3,23,26,40)$. Another effect is to bring the extradiegetic and diegetic planes together, as not only the spectator or "gazer" (10) but also the creatures in the painting "gaze" (1), be it instinctively, like the serpents from which "gleams a brazen glare" (34). The Shelleyan spectator is thus drawn into the spectacle, and the painting is like an eye watching him.

Even more than a contrast, there is an oxymoronic association of light and shade in the poem: not only is the "darkness" of the painting "visible," but love, which is usually bright, is described as a shadow, while pain, which is usually dark, is described as a light. Besides, like the words referring to the senses in the passage of "Prometheus Unbound" discussed above, light and shade are often connected syntactically, as in "a shadow, from which shine" (6), "the darkness and glare of pain" (15) and "the midnight sky / Flares, a light more dread than obscurity" (31-32). Light and shade even merge together, like Milton's "darkness visible," in "brazen glare," "watery rock" or "wet rocks" $(18,40)$ and "ever-shifting mirror" (37), if we consider that these things are at once dark, like the silver mail of the snakes, the brown ground dampened by Medusa's blood or a mirror reflecting something dark; and luminous, like the glistening mail and water or a mirror reflecting something bright. As a result, it is difficult to see where the light comes from, although the poet seems to point to the head's "shining shadow," the snakes' scales and a light in the midnight sky. Like the bat in the painting or Panthea watching the Sphere of the Earth or Prometheus, we are "bereft of sense" (27-28), especially when the gaze is turned into blindness, or the gazer to stone line 10, due to the absence of light, colour or even meaning, as the syntax is sometimes difficult.

This chiaroscuro and its oxymoronic associations are transposed onto an abstract plane, where they synesthetically objectify intangible emotions or mental states suggestive of light (beauty) or shade (terror and death), like "horror and its beauty are divine" (4), "less the horror than the grace" (9) or "loveliness of terror" (38). At the same time, the picture's light and shade is spiritualised, or, as Mary Shelley writes, "idealised:" "Loveliness like a shadow, from which shine, / Fiery and lurid, struggling underneath, / The agonies of anguish and of death" (6-8). When he describes anguish and death as shining, Shelley may only be referring to the silver mail of the writhing snakes which reflects, and is thus contaminated or redeemed by, the light and loveliness coming from Medusa's head. As to the obverse, the description of beauty as a "shining shadow," it is not paradoxical, first, if we recall the Madonna's "shadowed forth" maternal love, Prometheus's shadow of love tempering his sublime titanic light, or Asia's light of love obscured by the veil of the body, like the sun shining through cloud. 
Secondly, the shadow is Platonic; it mirrors the ideal light of the Good, which it at once 'mocks' and gives access to. Still, whereas the Good or Beautiful is the Ideal in The Republic, the same cannot be said of the "agonies of anguish and of death," which Plato would consider unfit for art. Shelley is not only a Platonist and, like Winckelmann, he can find delight in darkness, horror, despair or suffering experienced from a safe distance, provided it is tempered by light, beauty and softness, like the snake's "mailed radiance" which "mock[s]," that is to say, both imitates and challenges "The torture and the death within" (22-23). There is therefore a further synesthetic association when death and pain are described as luminous, and beauty as dark and painful. Following the Sturm und Drang movement and Edmund Burke's reflections and the beautiful and the sublime, Shelley challenges and regenerates received associations into "unapprehended relations of things." These oxymoronic synesthetic associations are not so different from the negative synesthesia like "mute light" which O'Malley said Shelley derived from Dante.

Besides, Shelley further develops the colour-harmony synesthesia (mixing sight and hearing), which he had already made ethereal and intangible in his Bolognese letter. That Pliny's harmogen was then synesthetic and not only a dead metaphor can be verified in "Tis the melodious hue of beauty thrown / Athwart the darkness and the glare of pain, / Which humanize and harmonize the strain" (1416). The "melodious hue" and polysemous "strain" explicitly associate music with colour to reinforce the unity and balance of the painting. The new synesthesia of "melodious hue" at once regenerate the old, dead one, "harmony" or "harmonize," by expanding it into what we may call a "subdued synesthesia." Typically, "harmonize," "melodious" and "strain" also associate the sense of hearing and abstract feelings or states, for which hues or rather light and shade are metaphors. It could be summarised thus: abstract things (love, beauty; pain, horror) $\rightarrow$ light and shade $\rightarrow$ music; or light and shade $\rightarrow$ abstract things (love, beauty; pain, horror) $\rightarrow$ music, with the arrows meaning "are described as." In "Prometheus Unbound," R. Fogle identifies "synesthetic example[s] of 'tonal vision,' or sound portrayed as light or color" (Imagery 129-130); what happens here could be called "audition colorée" (O’Malley 6) or light portrayed as sounds.

However, even here touch is more important, due to the physically painful subject of a severed head, but also the transformation of the picture into an ancient sculpture ("lineaments... graven"), as the lack of colour already implied. If "eyes" abound in the poem, there are also many "stones" ("peak," 2 , "stone," 10, 25, "rock[s]," 19, 40, "cave," 29) and even metal ("brazen," "mailed"), obviously because Medusa can "turn[s] the gazer's spirit into stone." The painting is thus solidified, like the "solid air" seen by the snakes and sawed "with many a ragged jaw" (24). The use of spatial prepositions in the synesthetic objectifications of beauty, terror and pain, also excites the sense of touch, as in "Upon its 
lips and eyelids seems to lie / Loveliness," which is reminiscent of death and pain in the ekphrasis of Guido's Samson. A similar effect is produced by the necessary use of such prepositions in the description of a visual image, as in "Upon the... mountain peak supine" (2) or "struggling underneath," 7), and more especially in "gazes on" (1), "peeps... into" (25) and "Out of the cave this hideous light hath cleft" (29), which look like dead synesthesiae suggesting sight and contact. As the last example and "turns the gazer's spirit into stone" show, Shelley also uses $/ \mathrm{k} /$ and $/ \mathrm{t} /$ alliterations, even in rhymes ("rock," "lock," "mock"), to suggest the hardness of stone. Light in this poem is often likened to fire, so that the senses of sight and touch are mixed together in "gleams a brazen glare / Kindled by that inextricable error" (34-35), while shuddering in "a thrilling vapour of the air" (36) and "seen tremblingly" (3) evokes both something visual and tactile. Finally, "[...] curl and flow, / And their long tangles in each other lock, / And with unending involutions" (19-21) is reminiscent of the unending curves and flowing forms of androgynous and adolescent statues in Praxiteles' Beautiful style, like the Venus Anadyomene described by Shelley in his "Notes on Sculptures" or in "The Birth of Pleasure." However, he only uses Winckelmann's style here to give shape to the complex "involutions" of the snakes, like those in The Laocoön group which the poet also described. The second fragment in Mary's copybook is more explicit as to the transformation of the painting into an ancient "fragment," which also objectifies life and death and associates them:

It is a trunkless head, and on its feature

Death has met life, but there is life in death,

The blood is frozen - but unconquered Nature

Seems struggling to the last — without a breath

The fragment of an uncreated creature. (The Poems 3:218-219)

While this transformation into a sculpture enables the poet to make the beauty of the Medusa more "everlasting" than the lost paintings of antiquity, it also makes it more tangible and tactile: Shelley can almost touch it.

\section{Conclusion}

Curiously, Shelley seldom uses synesthesia properly speaking to describe paintings, even though, as "unapprehended relations of things," they seem appropriate for ekphrasis and its evocation of the visual arts through words. When he does so, he only resorts to dead synesthesiae, like "warm colours" or the "harmony of colours," as in his juvenilia, although he somewhat regenerates them. 
In his description of Franceschini's warm colours, for instance, his synesthesia becomes surrealistic, while in the poem "On the Medusa" he develops Pliny's harmogen and tonon into "melodious hues" that "harmonize the strain" and a complex, oxymoronic chiaroscuro blending the "tangible" light and shade of the painting with abstract emotions and ideas. In either case, synesthesia betrays an aesthetic or even metaphysical epiphany.

Despite the scarcity of proper synesthesiae, his ekphrases can be described as synesthetic, firstly, when they associate words referring to the senses in a limited space, like a noun phrase, a line or a stanza. The effect is synesthetic, as the poet seeks, through a total synesthesia, a total experience that ultimately transcends the body and division of the senses. However, this happens more often in his poetry than in his prose ekphrases, which usually combine the intellectual senses of sight and hearing, with a strong suggestion of touch and rarer evocation of taste - smell is totally absent. Secondly, Shelley's "abstract imagination" often leads him to spiritualise colour and objectify emotions and ideas, which is sometimes akin to personification. It happens when Shelley resorts to ekphrastic prosopopeia or ventriloquism, or when he transposes the Italian chiaroscuro onto an abstract plane, where terror must be tempered by loveliness, as in the Beautiful style described by Winckelmann.

As part of the technique of pictorialism, particular words and even prosodic effects may suggest and excite other senses than hearing or even sight. In "On the Medusa" for instance, alliterations and words suggesting stone combined with the lack of colours transform the painting into sculpture, because Shelley is more at ease with the latter, which symbolises immortal art for him. Although the prosodic effects are more likely to be found in his poems, the poet sometimes resorts in his prose to polysemous words like "heavy" and "light" which potentially combine sight with other senses. Thus, the sense of touch often "contaminates" that of sight, so as to make the subject of the work of art more palpable and closer to the viewer, whether the sense of touch conveys some pain or a degree of erotic pleasure. Prepositions suggestive of contact may produce the same effect. It is also when the subject described is erotic or Dionysian than the sense of taste is added to the sense of sight through such polysemous words (or dead synesthesia) as "hazel" or "chestnut." 


\section{Works Cited}

BACON, Francis. The Advancement of Learning. 1605-23. Ed. Joseph Devey. New York: P.F. Collier and Son, 1901. BAKER, Carlos. Shelley's Major Poetry: The Fabric of a Vision. Princeton: Princeton University Press, 1948.

BENNESON MACMAHAN, Anna. With Shelley in Italy, Being a Selection of the Poems and Letters of Percy Bysshe Shelley which have to do with his Life in Italy from 1819 to 1822. Chicago: A.C. McClurg \& Co., 1905.

BONCA, Teddi Chichester. Shelley's Mirrors of Love: Narcissism, Sacrifice, and Sorority. Albany: State University of New York Press, 1999.

BONNECASE, Denis. Shelley et le complexe d'Icare. Lyon: Presses Universitaires de Lyon, 1990.

BURKE, Edmund. A Philosophical Enquiry into the Origins of Our Ideas of the Sublime and Beautiful. 1757. London: Routledge and Kegan Paul, 1967.

BUSH, Douglas. Mythology and the Romantic Tradition in English Poetry. 1937. Cambridge (Mass.): Harvard University Press, 1969.

CHEEKE, Stephen. "Romantic Hellenism, Sculpture and Rome." Word \& Image 25:1 (Jan.-Mar. 2009): 1-10.

COLWELL, Frederic S. "Shelley and Italian Painting." Keats-Shelley Journal 29 (1980): 43-66.

—. "Figures in a Promethean Landscape." Keats-Shelley Journal 45 (1996): 118-131.

DANTE, Alighieri. La Divine comédie (Divina Commedia, 1306-1321): L'Enfer / Inferno. 1985. Trans. from the Italian by Jacqueline Risset. Bilingual edition. Paris : GF-Flammarion, 2004.

DARWIN, Erasmus. The Botanic Garden. A Poem in Two Parts. 1791-94. London: J. Johnson. 2 vols. Vol. II.

—. The Temple of Nature; or, The Origin of Society: A Poem with Philosophical Notes. London: J. Johnson, 1803.

DESSET, Fabien. "Shelley's Uneasiness about Colour in his Poetry and Ekphrasis." Definitions of Color / De la Couleur. Eds. Frédéric Ogée and Maurice Géracht. Interfaces 33. Worcester: College of the Holy Cross, Paris: Université Paris Diderot, Dijon: Université de Bourgogne, 2012. 165-192.

"La Peinture antique à travers le palimpseste plinien de P.B. Shelley." Transparence romantique. Ed. Fabien Desset. Limoges: Pulim, 2014. 81-101.

DOWNEY, June E. "Literary Synesthesia." The Journal of Philosophy, Psychology and Scientific Methods 9:18 (Aug. 1912): 490-498.

- Creative Imagination: Studies in the Psychology of Literature. New York: Kegan Paul, Trench, Trubner, 1929.

EIGELDINGER, Mark. Mythologie et intertextualité. Genève: Slatkin, 1987.

ERHARDT-SIEBOLD, Erika von. "Synästhesien in der englischen Dichtung des 19. Jahrhunderts. Ein ästhetischpsychologischer Versuch." Englische Studien 53 (1919): 1-334.

FIRKINS, Oscar W. Power and Elusiveness in Shelley. Minneapolis: University of Minnesota Press, 1937.

FOGLE, Richard Harter. The Imagery of Keats and Shelley. Chapel Hill: University of North Carolina Press, 1949. "Image and Imagelessness: A Limited Reading of Prometheus Unbound." Keats-Shelley Journal 1 (Jan. 1952): 23-36.

GOETHE, Johann Wolfgang. Faust I (Faust: Der Tragödie erster Teil). 1806. Illustrated by Friedrich August Moritz Retzch. Trans. from the German attributed to S.T. Coleridge. London: Thomas Boosey and Sons, 1821. 
HEFFERNAN, James A.W. Museum of Words: the Poetics of Ekphrasis from Homer to Ashbery. Chicago: University of Chicago Press, 1993.

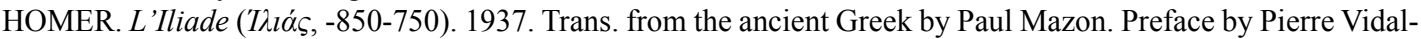
Naquet. Paris : Gallimard, 1975.

HORACE, Quintus Horatius Flaccus. Ars Poetica or Epistle to the Pisos [De Arte Poetica]. 14 B.C. In Satires, Epistles, Ars Poetica. Trans. from the Latin by Harry Rushton Fairclough. London: William Heinemann LTD, Cambridge (Mass.): Harvard University Press, 1970.

JONES, William. Physiological Disquisitions: or, Discourses on the Natural Philosophy of the Elements. 1781. The Theological, Philosophical and Miscellaneous Works of the Rev. William Jones. London: F. and C. Rivington, 1801. 12 vols. Vols. IX-X.

LESSING, Gotthold Ephraim. "Laocoon, Des Limites de la peinture et de la Poésie, et de ce que ces deux arts peuvent emprunter l'un de l'autre" (Laokoon oder über die Grenzen der Mahlerey und Poesie). 1766. Trans. from the German by Hendrik J. Jansen. In Winckelmann, Euvres 1: 602-625.

MILTON, John. Paradise Lost. 1667. Ed. John Leonard. London: Penguin Books, 2000.

NEWTON, Isaac. Opticks: or, a Treatise of the Reflections, Refractions, Inflections and Colours. 1704. London: William Innys, 1730.

NOTOPOULOS, James Anastasios. The Platonism of Shelley: A Study of Platonism and the Poetic Mind. Durham: Duke University, 1949.

O’MALLEY, Glenn. Shelley and Synesthesia. Evanston (Ill.): Northwestern University Press, 1964.

O'SULLIVAN-KÖHLING, Ilsa. Shelley und die bildende Kunst. Halle: Max Niemeyer, 1928.

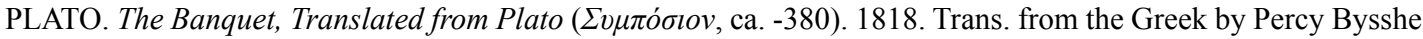
Shelley. In Notopoulos 402-460.

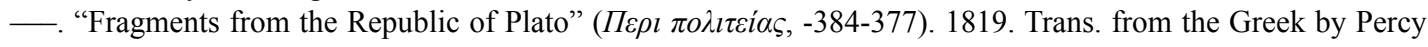
Bysshe Shelley. In Notopoulos 490-501.

PLINY. Natural History in Ten Volumes (Naturalis Historia, ca. 77). 1952. Trans. from the Latin by Harris Rackham. London: William Heinemann LTD. Cambridge (Mass.): Harvard University Press, 1968. 10 vols.

SHELLEY, Percy Bysshe. The Poetical Works of Percy Bysshe Shelley. 1824. Ed. Mary Wollstonecraft Shelley. London: Edward Moxon, 1839.

- The Complete Poetical Works of Shelley. 1904. Ed. Thomas Hutchinson. Corrected by G.M. Matthews. Oxford: Oxford University Press, 1970.

—. Poems Published in 1820. Ed. Arthur Montague d'Urban Hughes. London: Oxford University Press, 1910.

- The Complete Works of Percy Bysshe Shelley. Eds. Roger Ingpen and Walter E. Peck. London: Ernest Benn, 1926-1930. 10 vols.

—. Shelley's Prose; or, the Trumpet of a Prophecy. 1954. Ed. David Lee Clark. Preface by Harold Bloom. New York: New Amsterdam Books, 1988.

- The Letters of Percy Bysshe Shelley. Ed. Frederick Lafayette Jones. Oxford: Oxford University Press, 1964. 2 vols. 
—. Shelley's Poetry and Prose. Eds. Donald H. Reiman and Sharon B. Powers. New York, London: W.W. Norton \& Company, 1977.

—. The Poems of Percy Bysshe Shelley. 1988-1989. Eds. Kelvin Everest et al. Harlow: Pearson Education, 20002011. 3 vols.

STAËL-HOLSTEIN, Anne Louise Germaine Necker de. Corinne, ou l'Italie. 1807. Ed. Simone Balayé. Paris: Gallimard, 1999.

_. De L'Allemagne. Eds. Pauline de Pange and Simone Balayé. Paris: Hachette, 1958-59. 4 vols.

WALKER, Adam. A System of Familiar Philosophy: In Twelve Lectures. London: printed for the author, 1802.2. Vols.

WEBB, Timothy. "Romantic Hellenism." The Cambridge Companion to British Romanticism. Ed. Stuart Curran. Cambridge: Cambridge University Press, 1993. 148-176.

WINCKLEMANN, Johann Joachim. Reflections on the Painting and Sculptures of the Greeks. 1755. Trans. from the German by Henry Fuseli. London: Merston Soblar Press, 1972.

- Euvres complètes (or, through a synecdoche, Histoire de l'art chez les Anciens [Geschichte der Kunst des Altertums. 1764], published in the first two volumes). Trans. from the German by Michel Huber. Ed. Hendrik J. Jansen. Paris: Chez Etienne Gide, 1801-1803. 3 vols.

ZILLMAN, Lawrence J. Shelley's 'Prometheus Unbound:' A Variorum Edition. Seattle: University of Washington Press, 1959.

\section{Art Works Cited}

BANDINELLI, Baccio. Laocoön (Laocoonte). Copy of the 120-20 B.C. marble group by Agesandros, Athenodoros and Polydorus (in the Vatican Museum). 1520-1525. Uffizi Gallery, Florence.

BERGONDI, Andrea. Sleeping Hermaphrodite. II ${ }^{\text {nd }}$ century Roman copy of the original Hellenistic bronze by Polycles of 150 B.C. restored in 1781 by Andrea Bergondi (head and left leg). Palazzo Borghese, Rome.

BOTTICELLI, Sandro. The Birth of Venus (La Nascita di Venere). Ca.1485. Oil on Canvas. Uffizi Gallery, Florence.

CORREGGIO, Antonio Allegri. The Saviour (Il Redentore or Cristo in Gloria tra Cherubini). Oil on canvas. Ca. 1525. Museum of the Vatican, Rome.

FRANCESCHINI, Marcantonio. Charity (Carità). Oil on canvas. 1641. Gemäldegalerie Alte Meister, Kassel.

- Charity (La Carità). Oil on canva. Ca 1680. Banco Popolare di Verona e Novara, Verona.

- Assumption of Saint Catherine Vigri (Assunzione della Santa). Fresco. 1687-1694. Formerly on vault of the church of Corpus Domini, Bologna.

- Annunciation (Annunciazione). Oil on canvas. 1700. Church of the Osservanza, Cesena.

-. Annunciation (Annunciazione). Oil on canvas. 1726. Church of Sant'Isaia, Bologna. 
FUSELI, Henry (Füssli, Johann Heinrich). The Artist in Despair Before the Grandeur of Antique Fragments (Der Künstler verzweifelnd vor der Grösse der antiken Trümmer. Red chalk on sepia wash. 1778-1779. Kunsthaus, Zurich.

MICHELANGELO, di Lodovico Buonarroti Simoni. The Last Judgment (Il Giudizio Universale). Fresco. 14361541. Sistine Chapel, Vatican.

RENI, Guido. The Triumph of Samson (Sansone vittorioso). Oil on canvas. 1611-1612. Pinacoteca Nazionale, Bologna.

—. Crucifixion of the Capuchins (Gesù Cristo Crocifisso, la Vergine Addolorata, Santa Maria Maddalena e San Giovanni). Oil on canvas. Ca. 1617. Pinacoteca Nazionale, Bologna.

-. Madonna and Child (Madonna che allatta il bambino). Oil on Canvas. 1628-1630. Raleigh Museum of Fine Arts, North Carolina.

- Fortuna Restrained by Love or with a Purse (la Fortuna trattenuta da Amore). Oil on canvas. 1637. Pinacoteca, City of the Vatican. (another version, with a crown, is in a private collection)

-. St Mary Magdalene (Santa Maria Maddalena). Oil on canvas. 1633. Galleria Nazionale d'Arte Antica, Rome. [as an example of Guido's Magdalenes]

SCOPAS (attributed). The Niobe. Roman copy of the original Hellenistic work of the III ${ }^{\text {rd }}-I^{\text {nd }}$ century B.C. Uffizi Gallery, Florence.

RAPHAEL (Raffaello Sanzio da Urbino). The Ecstasy of St. Cecilia (Estasi di Santa Cecilia). Oil transferred from panel to canvas. 1514-1516. Pinacoteca Nazionale, Bologna.

TITIAN (Tiziano Vecellio). Danae. Oil on Canvas. 1544-1546. Museo Nazionale di Capodimonte, Naples. Formerly in the Palazzo degli studi.

VINCI, Leonardo da (attributed, in fact by an unknown Flemish artist). The Head of Medusa. Oil on wooden panel. Ca. 1600. Uffizi Gallery, Florence. 